\section{Visit Russia, help science}

SIR - Scientific journals regularly describe the continuing decay of Russian science. The cumbersome, highly redundant Russian scientific system has indeed collapsed with the Soviet Union. Although only a few research laboratories have been closed, the contraction of the scientific enterprise is inevitable, despite the traditional belief that a scientist has a job for life. Today, Russian scientists are underpaid, they have inadequate working conditions, they must endure hardships in everyday life and, as result, they leave science or the country.

Does this mean that Russia does not need scientists and that Russian science will eventually cease to exist? The answer is definitely no. Russias badly needs scientists and science to become an integral part of the developed world. Without science, a modern society cannot provide a secure and decent life for its people.

Fortunately, the present situation is not as desperate as it might seem. There are still scientists who work effectively and have decided to stay in Russia. Bright students are still attracted to science. There are still places of excellence, research laboratories and institutes with a solid international reputation in which good science is done. They can serve as focal points for the recovery of Russian science. But they are in urgent need of help. Scientists must have access to the literature, reagents, equipment and international meetings and, of course, they must have adequate salaries. And help is coming through Russian government scientific programmes, sometimes from their own commercial activities, and, essentially, from international grants and contracts with foreign companies and Western foundations.

But Russian science will inevitably shrink and only the best should remain. Who will survive? These decisions should not be made only by the government or by the academic hierarchy. If they are, the choices may be based on political considerations rather than on the quality of the science. The research enterprise must undergo quality selection, like its counterparts in the West. Research groups will have to take a much more aggressive approach to survival. They must compete for support, for grants and for scientists of the highest calibre. The vacancies created by the devastating brain drain from the best Russian institutions should be filled from both inside and outside the country to keep science running. The feudal system within which most Russian scientists spent their entire careers as subordinates in just one place is dying, for better or worse. A demand for scientists will develop. In the near future, advertisements for positions in Russian research centres are likely to appear in international journals.

The situation at the Engelhardt Institute of Molecular Biology is no exception: we too are struggling for survival. The institute is a leader in molecular and cell biology and in human genome studies. But, like many other institutes, we have recently endured a period when we found it very difficult to maintain scientific productivity. Fortunately, the institute has sufficiently good facilities and equipment to be internationally competitive and it has succeeded in retaining a core of outstanding scientists. They have continued to work productively and, surprisingly, the number of publications in leading international journals has continued to increase. We have maintained our traditions of scientific openness, cooperation and independence. The institute actively participates in several state scientific programmes; for example, it is the leading institute in the Russian Human Genome Project. We maintain close contacts with many Western laboratories. All this has proved useful in winning Russian and international grants to cover research expenses and salaries.

However, the institute has not escaped the impact of the brain drain. We now have a number of positions available at various levels, ranging from technicians to laboratory heads. We are inviting both Russian and foreign researchers to apply for these positions, which have a tenure of 2 to 5 years. On request, we shall send a brochure about the institute. A sojourn in Russia is both challenging and attractive. Andrei D. Mirzabekov

Engelhardt Institute of Molecular Biology, Russian Academy of Sciences,

Moscow 117984,

Russia

Fax (7095) 1351405

\section{Problem-solving}

SIR - In various places (for example Nature 361, 571; 1993), you have expressed your views concerning the (re)organization of British science. You conclude that academic research should be primarily educational, and that education should be in problem-solving. Thus far, I, an industrial scientist, am in agreement.

Then we part company. You hold that apprenticeship in production management does not teach problem-solving. You would be right if plant and factory ran as smoothly as they should. As they never do, managing them demands problemsolving of an ingenuity seldom shown in academic life under pressures professors have never dreamt of. Production mana- gers, very properly, detest innovation they have learnt that the state of the art is down and that infant technologies are always unable to compete with the mature ones they will grow to supplant.

My colleagues and I and my more reflective academic friends have long been alarmed at the increasing number of production lines in academic research, in big science and elsewhere. There are many projects that consist of tedious repetition of one simple experiment to amass data which, combined with those from numerous similar slave labourers, might conceivably solve a problem some decades hence. The stamp collectors of high-energy physics are at this game and it is a fair description of the gene-sequencing at the heart of molecular biology. We are meeting potential recruits with doctorates in handle-turning and machine-minding.

If you were to ask my managerial colleagues who were their best problemsolvers in the 25-30 age group, they would not say the young PhDs. Their answer would be the technicians who have done part-time degrees while working in our research laboratories. For this there is another reason. If it can be solved in the library, or merely by taking thought, it is either no problem or not research. Problems, the innate malice and perversity of matter and men, must be fought hands-on and with sleeves rolled.

The average academic now ceases to engage in hands-on research shortly after the age of 30 , thereafter becoming a part-time administrator of research students. At this age, the industrial $\mathrm{PhD}$ is still learning his craft, full-time without teaching duties. This he will eventually pass to the next generation by example, not by lecture-hall harangue.

The result is that the real expertise in, say, synthetic organic chemistry is not in the Universities of Nottingham or Cambridge, to name two highly praised exemplars, but in the pharmaceutical research divisions of industry. Fortunately for academics, the managerial classes share the general anthropological belief that foreign magic is more powerful than domestic magic.

If we in industry encounter a problem that might or might not yield to a great deal of tedious and repetitive research but is not vital, we commonly look for an academic collaboration. There are always academics looking to fund amental research and willing to sentence a graduate to it. To my shame, I have sometimes been involved in the supervision of such projects, for which reason I use a pseudonym.

To meet our aims, academic life needs transformation unlikely to be achieved by those who have lived entirely in the present structure.

Simon Roman

2 Upper Rosemary Hill,

Kenilworth CV8 2PA, UK 